\title{
Completion of Milestone 2.2.4.2.2/FY01/A "Completion of Mechanical Assembly of PuCTF in the Plutonium Facility"
}

W. Brummond, and G. Armantrout

March 2, 2001

U.S. Department of Energy

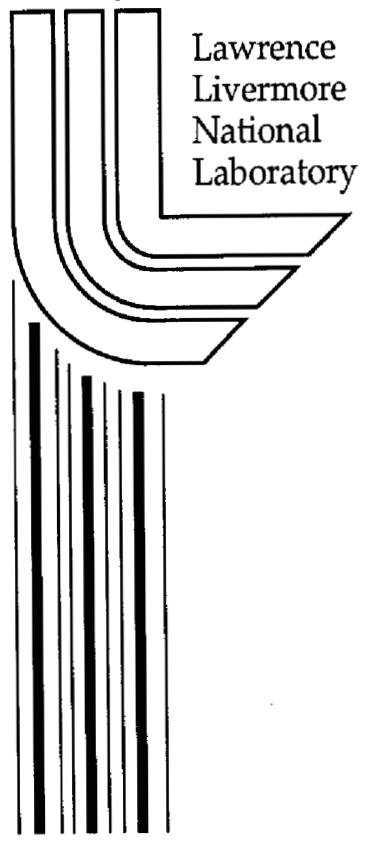




\section{DISCLAIMER}

This document was prepared as an account of work sponsored by an agency of the United States Government. Neither the United States Government nor the University of California nor any of their employees, makes any warranty, express or implied, or assumes any legal liability or responsibility for the accuracy, completeness, or usefulness of any information, apparatus, product, or process disclosed, or represents that its use would not infringe privately owned rights. Reference herein to any specific commercial product, process, or service by trade name, trademark, manufacturer, or otherwise, does not necessarily constitute or imply its endorsement, recommendation, or favoring by the United States Government or the University of California. The views and opinions of authors expressed herein do not necessarily state or reflect those of the United States Government or the University of California, and shall not be used for advertising or product endorsement purposes.

This work was performed under the auspices of the U. S. Department of Energy by the University of California, Lawrence Livermore National Laboratory under Contract No. W-7405-Eng-48.

This report has been reproduced

directly from the best available copy.

Available to DOE and DOE contractors from the

Office of Scientific and Technical Information

P.O. Box 62, Oak Ridge, TN 37831

Prices available from (423) 576-8401

http://apollo.osti.gov/bridge/

Available to the public from the

National Technical Information Service

U.S. Department of Commerce

5285 Port Royal Rd.,

Springfield, VA 22161

http://www.ntis.gov/

OR

Lawrence Livermore National Laboratory

Technical Information Department's Digital Library

http://www.llnl.gov/tid/Library.html 
TO: GUY ARMANTROUT

FROM: WILLIAM BRUMMOND

SUBJECT : Completion of milestone 2.2.4.2.2/FYOl/a "Completion of Mechanical Assembly of PuCTF in the Plutonium Facility"

The subject milestone was completed on March 1st. This milestonc signifies the completion the mechanical installation and assembly of PuCTF in room 1345 in the LLNL Plutonium Facility. This installation included equipment both in room 1345 and in the loft. As reported in the last milestone, "LLNL Pu Facility space prepared for installation of PUCTF", milestone 6.2.2/FYOO/c, steel plates had been installed on the floor to support the PuCTF glovebox and equipment. The steel plate system was a substantial holp in completing the mechanical installation reporled here.

The glovebox sections were brought into the room and attached togelher. Temporary scismic tie-down straps were used to brace the assembly. This temporary tie-down also provided flexibility for aligument and adjustment. The internal equipnent, (attritors, granulator, press feed shoe and die set, furnace, robot and powder transport system) were subsequently installed. The glovebox was then welded to the steel plates for permanent seismic anchoring. The control racks were attached to the floor and are rcady for wiring and the press hydraulic power unit has been installed in the loft.

The next steps will be to complete the electrical wiring and connections, conuect the utility lines and to check out the system. When this is completed in June, we will meet the next milestone for cold start-up of PuCTE. 


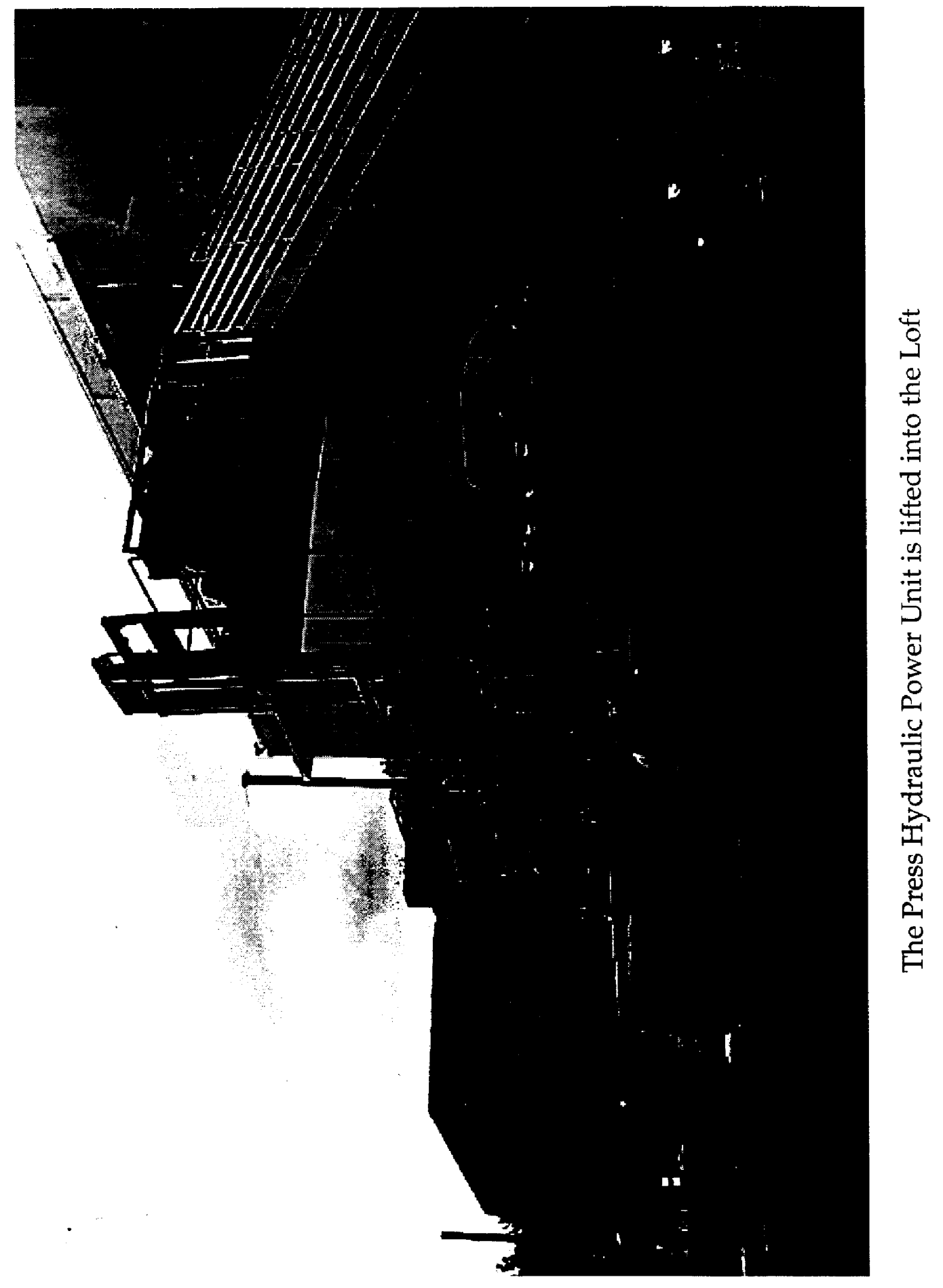




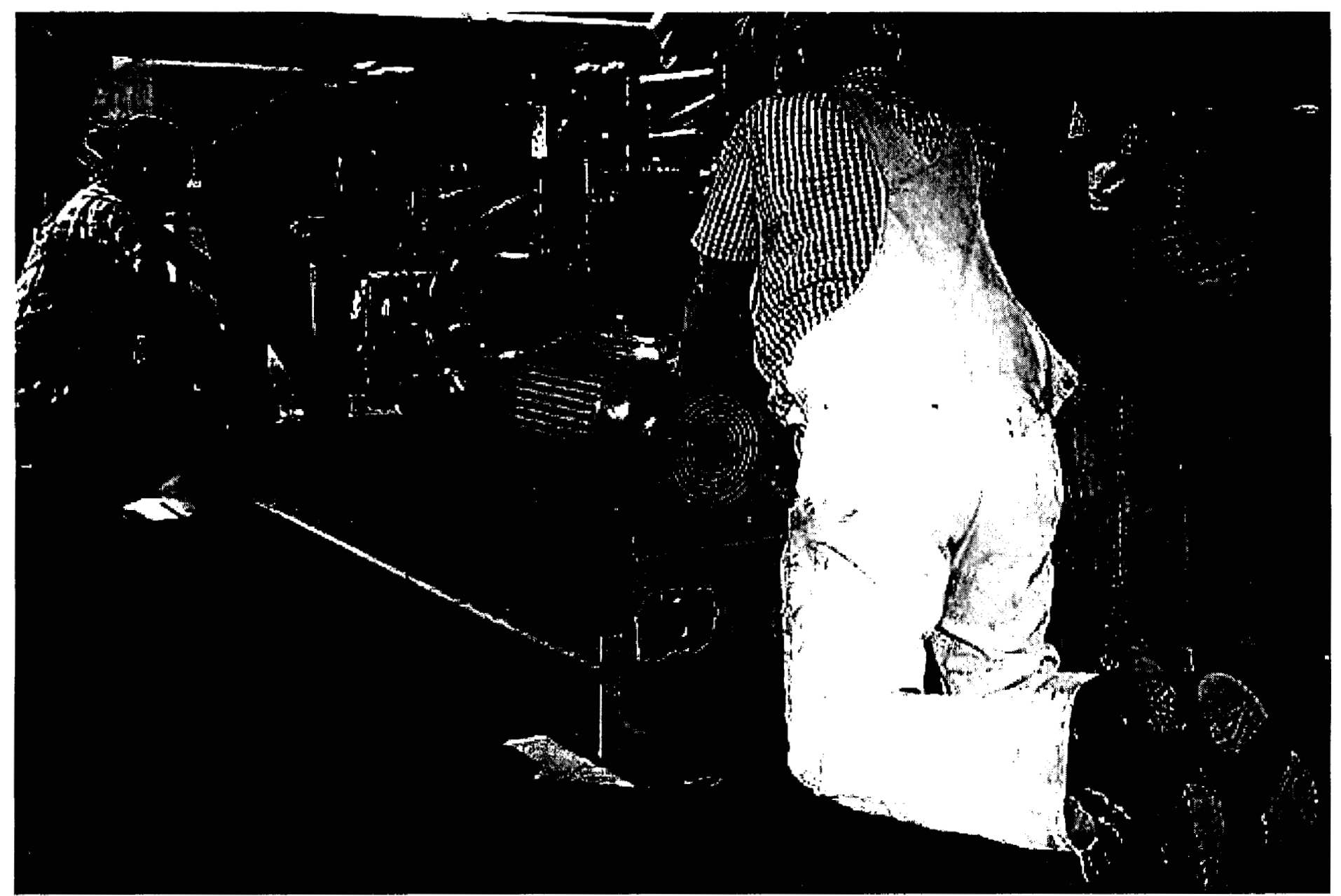

The Press Hydraulic Power Unit is anchored to the floor in a steel pan 


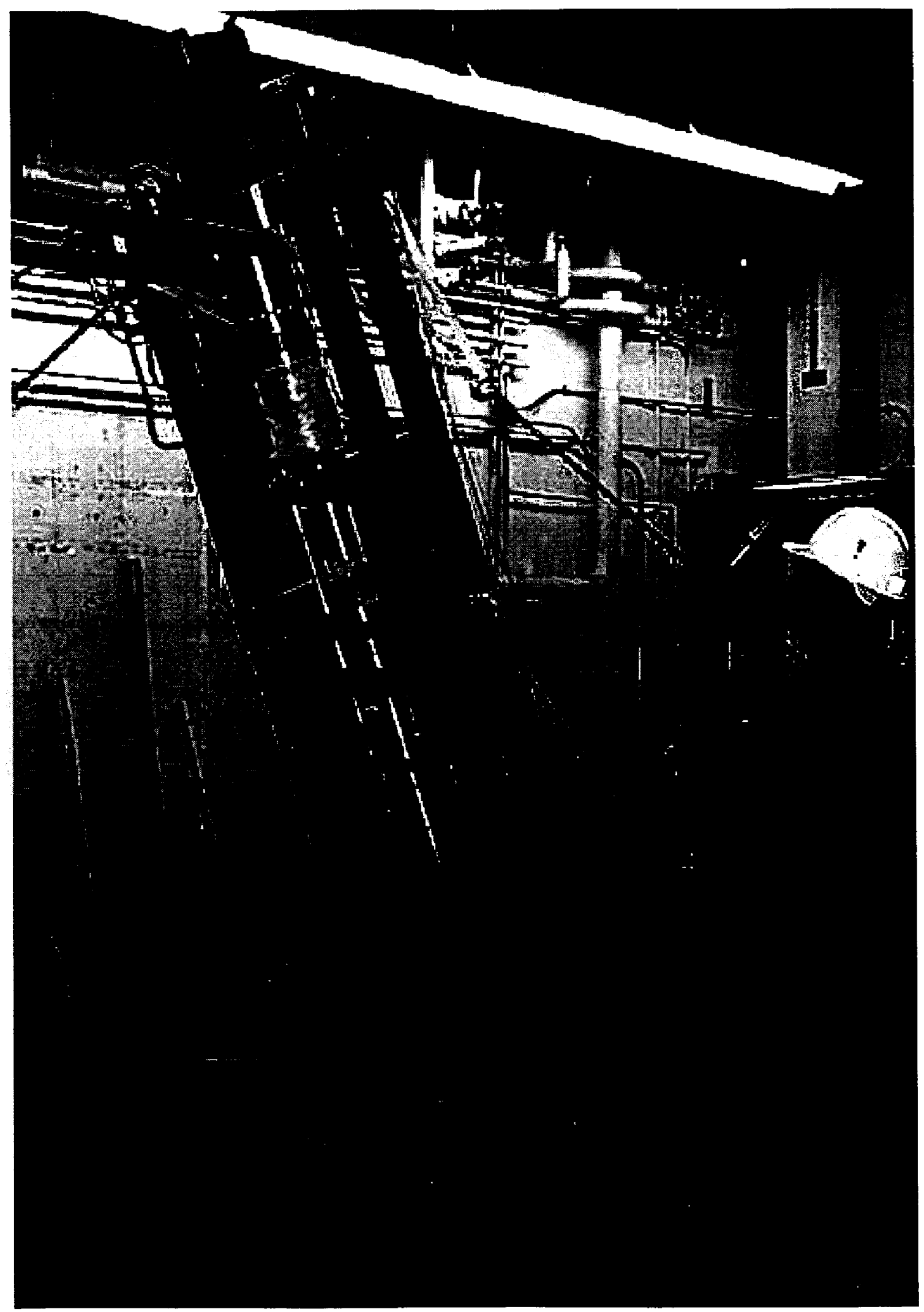

Righting the Press 


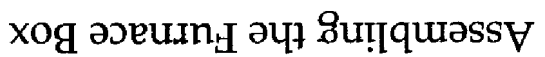

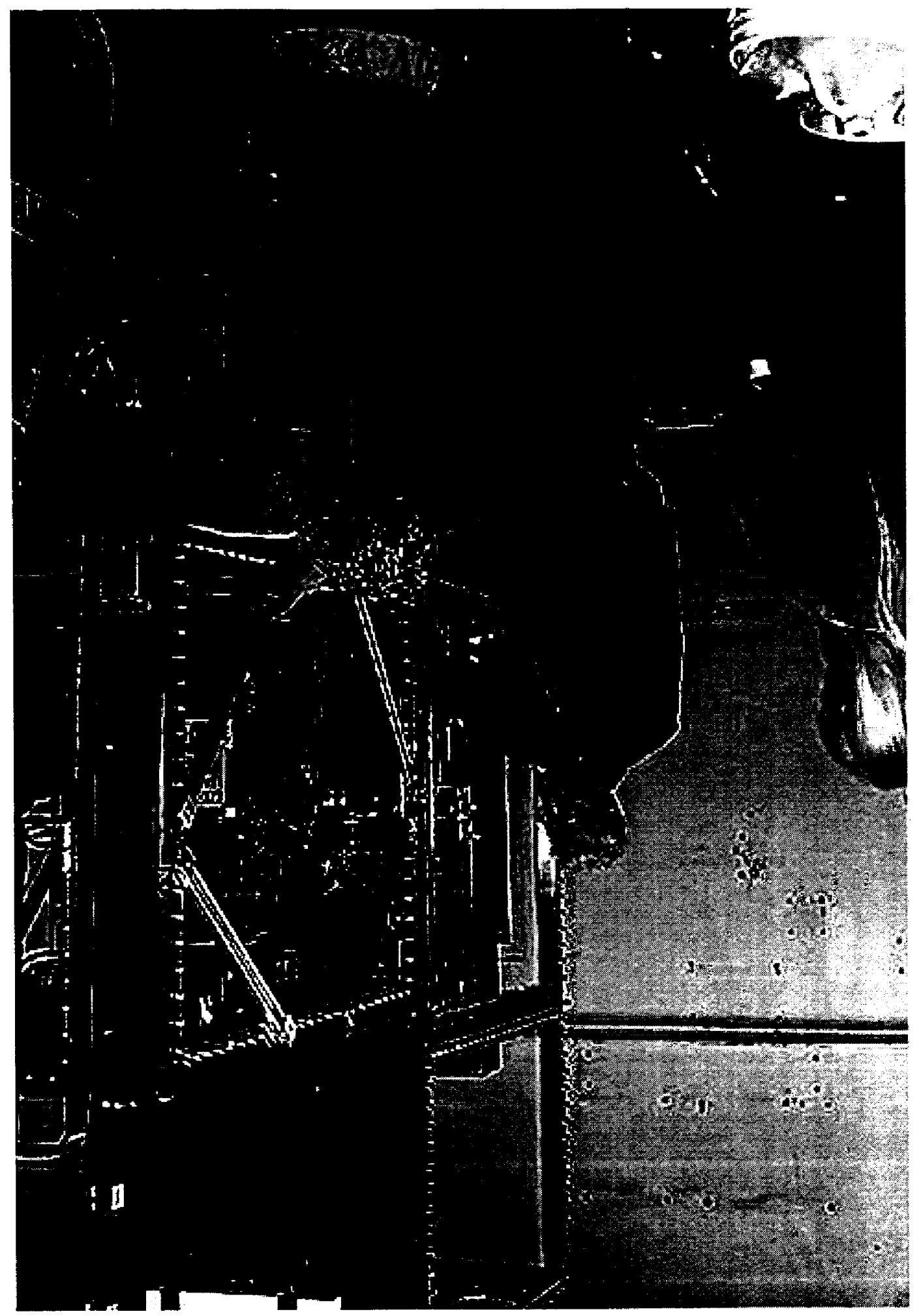



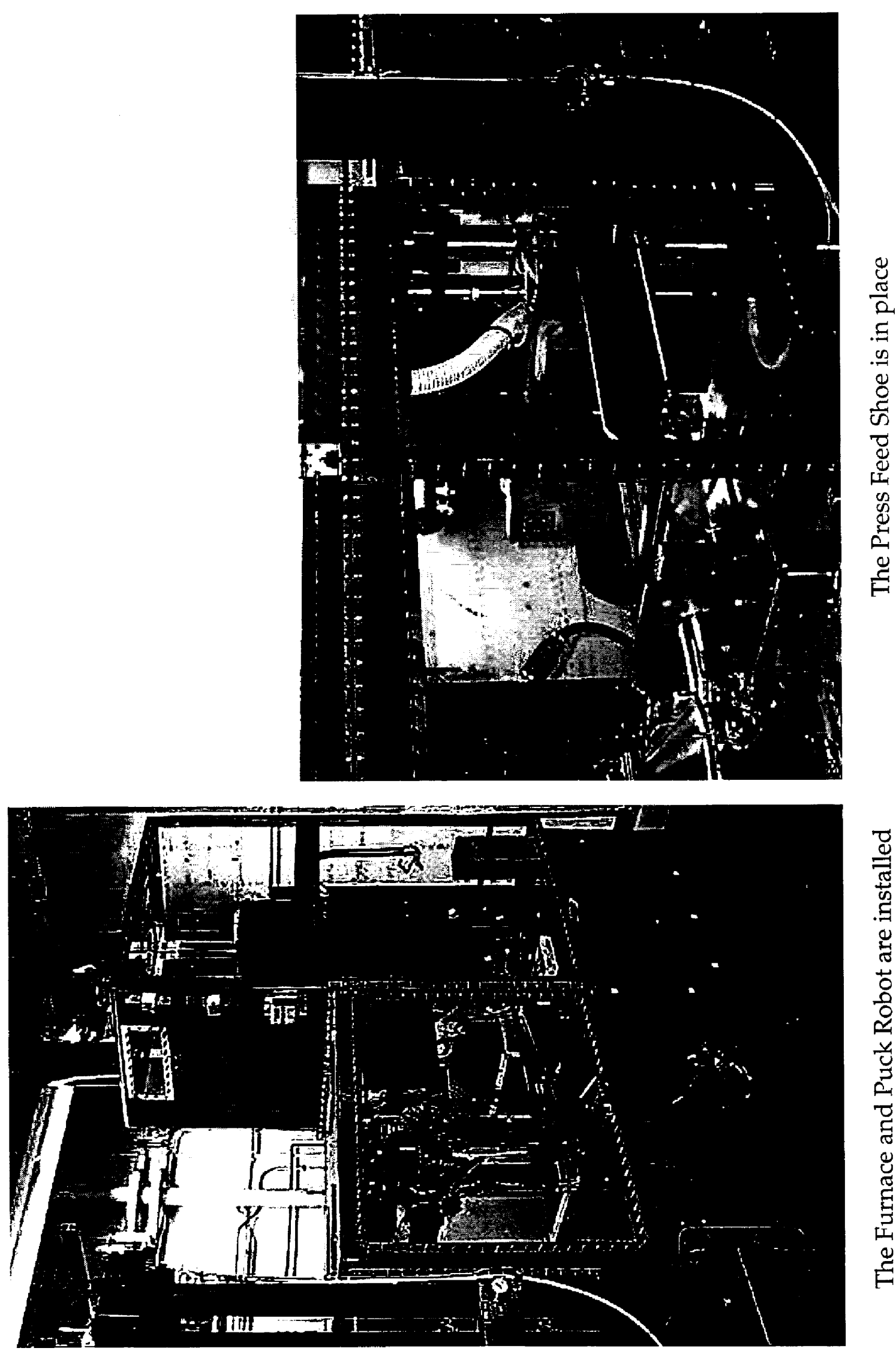

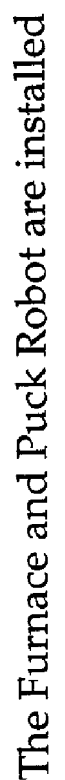






The Granulator is placed over the long axis Of the Material Transport System

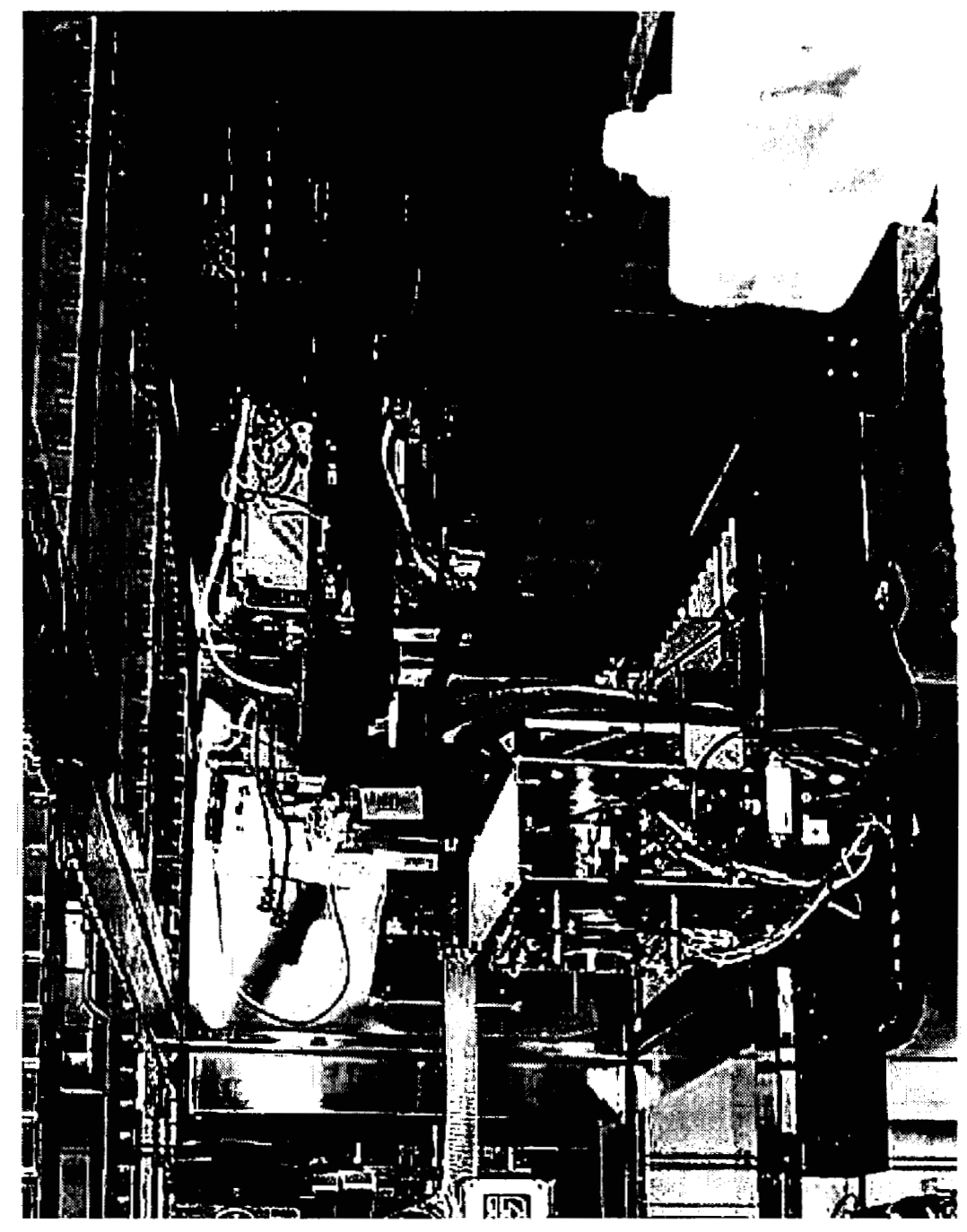

The Transport/Granulator docking station 


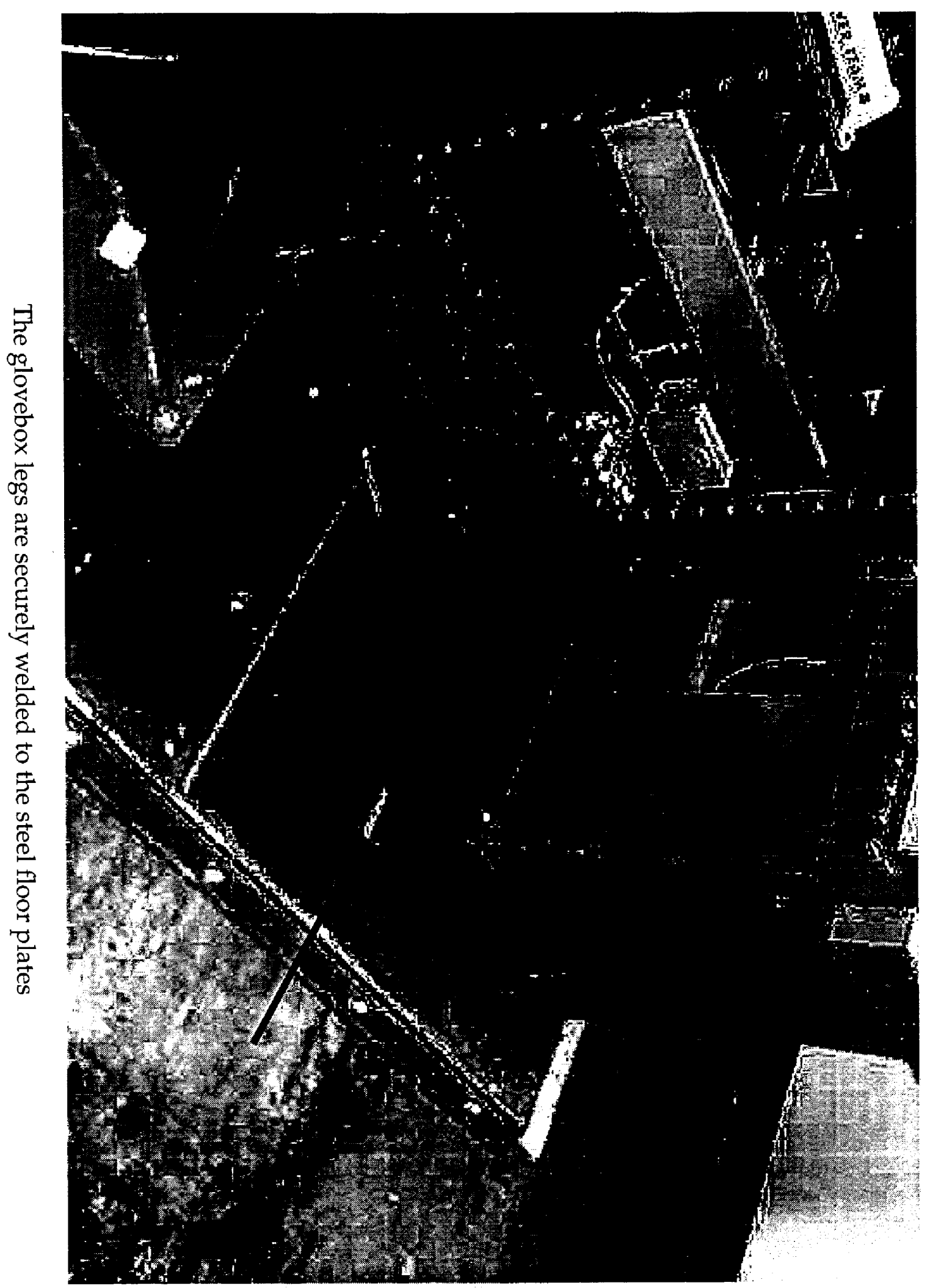




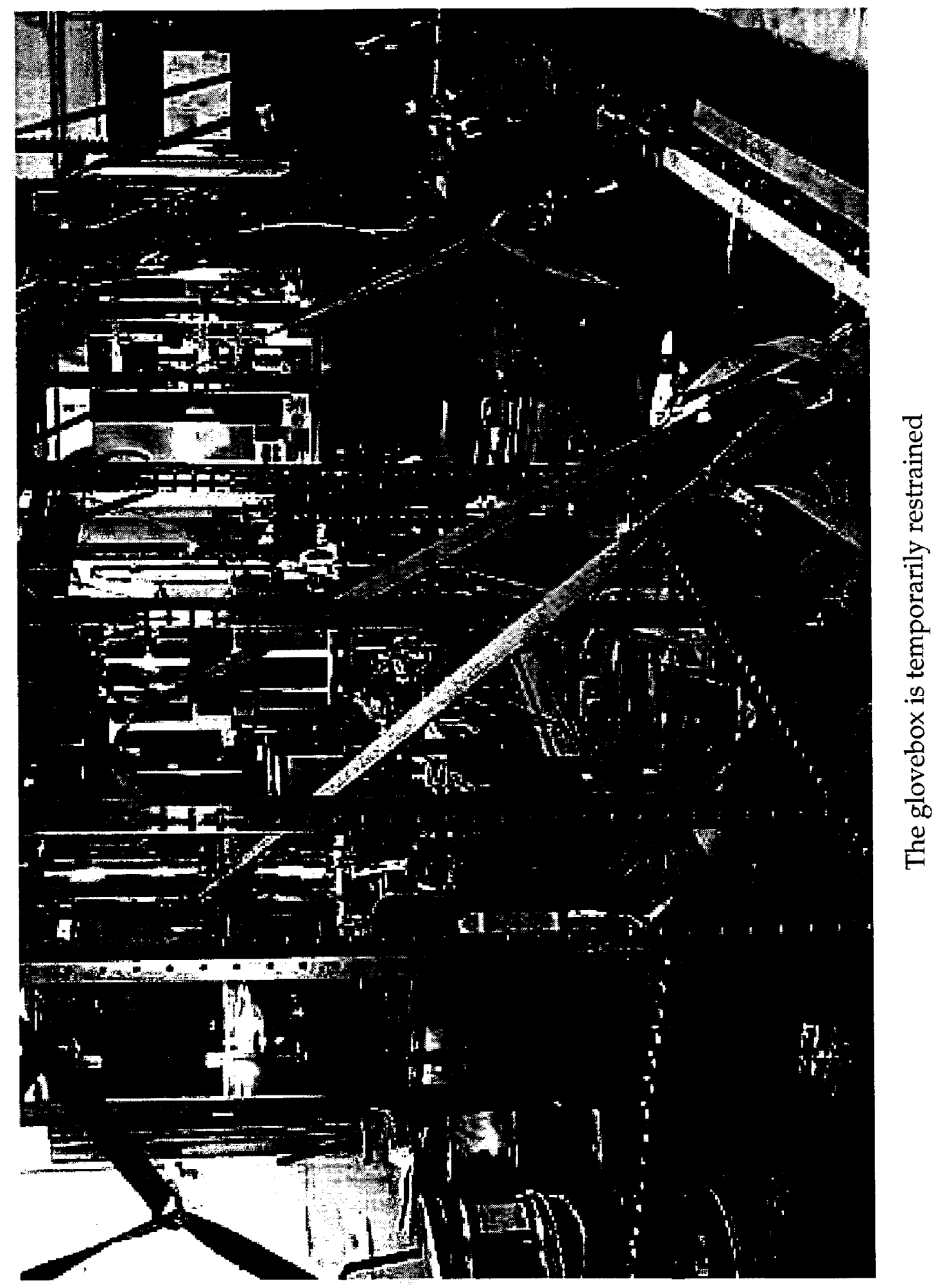

